\title{
CONCEPTUAL AND INSTITUTIONAL ADAPTATION OF SECURITY: REDEFINING NATO'S ROLE, IDENTITY AND STRATEGY IN THE NEW EUROPEAN CONDITION
}

KOSTAS IFANTIS

\section{Introduction}

This article is about how change at the international system level has produced those political outcomes related to sccurity and defence design in the 1990 s Europe. It is both a description and cvaluation of the way the European security arena has changed as well as an attempt to come to terms with the process that led to 'internalisation' of system change. By using the term 'internalisation' we mean the process, or better, the causal relationship between system change and policy response. Our argument is that the nature of the post-Cold War systemic reality has becn instrumental in sustaining and even increasing actors' faith in co-operative frameworks and in further collective behaviour and interaction in European security and defence.

Although highly unoriginal, there is no other way but to indicate, right from the beginning, that history and geography, which tight bipolarity had kept in limbo for over forty years, have re-emerged as factors reconstituting Europe's identity. The scope of political change, the rapidity with which events are known the world over, and the complexities involved in trying to understand the new security challenges have been and continue to be discussed. Our traditional conception of the classic factors of power in analysing and explaining the changing security environment is still relevant. The difference today is the reach of impact, the complexity of the causal process, the range and capabilities of actors involved, and the 
acknowledgement that threat and response are no longer within the sole or even primary purview of the military'.

Against this background, the discussion in the following pages addresses two important dimensions of current international concern: firstly the evolution of the European security system as we approach 2000. It takes account of the changing propertics of world politics since the collapse of bipolarity and attempts to assess the extent to which structure, power and actors have acquired new meanings under the impact of uncertainty and unpredictability that have followed the tectonic shifts in world affairs. Secondly, the extent to which the strategic ramifications of the new geopolitical realities and the new security challenges, although lacking a unificd concept of threat, can adequatcly 'provide' rules for statc interaction and most importantly for gradually reinforcing 'institutionalisation' of security. In the context of the latter, the analysis is directed towards the examination of NATO's institutional response and adaptation to the new structural clements and assesses the development of strategies, both national and institutional, as well as the formulation of effective policies.

\section{2. (Re)conceptualizing Security in the 1990s}

Any discussion about the prospects of a new system of collective security in Europe - as they have been expressed through the decisions taken in Maastricht, Amsterdam, Berlin and Madrid - should take account of the constituent elements of change that produced the 'new order'. ${ }^{2}$ This 'new world order' has come to symbolise, for many, a set of expectations and hopes, few of them strikingly clear or well articulated, and even fewer so far fulfilled. If there is to be a new order it will have to emerge not simply out of the ashes of the old, but rather in a dynamic tension with the powerful legacy of great-power war and resulting international institution-building during this century. There is, therefore, a critical evaluation problem which is linked to the need for conceptualization of the changing 'European order'.

${ }^{1}$ D. B. Dewit, Introduction: The New Global Order and the Challenges of International Security', in D. Dewitt, D. Haglund and J. Kirton (eds.), Building a New Global Order: Emerging Trends in International Security, Toronto, 1993, p.1.

${ }^{2}$ With the term 'order' we mean a formal or informal sum of relations which produces regular and expected patterns of behaviour and in which commonly accepted views on issues of hierarchy, legitimacy and normative interaction prevail. See, for example, R. Cox, Approaches to World Order, Cambridge, 1996, especially chapter 6. For a historico-sociological approach, see J. A. Hall, International Orders, Cambridge, 1996, especially chapter 1 . 
There are, essentially, four dimensions to this problematique: the first has to do with the nature and character of 'order' in gencral. The second has to do with the concept of change. The third concerns the response(s) to the process and the products of change, and the fourth addresses 'the issue of impact, and the ways in which changes in the order and in the actions of major participants feed into further processes of change' that influences both the nature of the whole (system) and the bchaviour of the parts (statc or other units). ${ }^{3} \mathrm{At}$ an cmpirical level, the changing nature of the order can be linked to a series of important developments. First and foremost, it is the existence of structural change that produces a rearrangement of European state relationships especially in the ficld of world economy. More and more, 'globalization' cnhances the interdependence of national economies, and undermines the traditional relationship between state power and market. Globalizing production and global finance transforms global economy into a system of 'governance without government'. 4

Closely linked with this process, is the emergence of new states in Europe and hence the necd to trace the components of the new European system. At the same time, revision of the economic and security status outside Europe have raised questions about the boundaries of the system and the interests of the European state actors. More often than in the past, there are new and sometimes unexpected linkages between political, sccurity and economic concerns, which have challenge the capacity of the state both to recognize and to respond to new challenges and needs for action. Finally, there has been an institutional challenge relating to the adcquacy of existing institutions for international action, and to the potential for coordination between statc and other non-state (transnational and subnational) forces.

${ }^{3} \mathrm{M}$. Smith, 'Beyond the Stable State? Foreign Policy Challenges and Opportunities in the New Europe', in W. Carlsnaes and S. Smith (eds.), European Foreign Policy: The EC and Changing Perspectives in Europe, London, 1994, p. 24. Smith altempts to approach the problems of foreign policy analysis in the framework of change in Europe. He discusses the implications of change for 'European state' by loking for the linkages between the tools of foreign policy analysis and state theory. In this exercise, the primary sources are those provided by J. Ikenberry and his work on 'The State and Strategies of International Adjustment', World Polltics, Vol. 39(1), 1986, and R. Cox and his work on 'States, Social Forces and World Order: Beyond International Relations Theory', in R. Keohane (ed.), Neorealism and its Critics, New York, 1986 as well as 'Multilateralism and World Order', Review of International Studies, Vol. 18 (2), 1992.

${ }^{4}$ On this notion, see J. N. Rosenau and E. Czempicl (eds.), Governance Without Government: Order and Change in World Politics, Cambridge. Also, S. Strange, Casino Capitalism, Oxford, 1986. 
This last issue is of paramount importance for Europe: European transnational forces combined with fragmenting subnational forces create ambiguity anf fuidity. The Europcan Union forms an 'island of peace' - a unity of transnational networks and a common retrenchment from a violent periphery. Paradoxically, however, these processes are also reproduced within the single state with national networks, sccurity zones and areas of violence. Transnational forces and the growth of cosmopolitanism have wcakened the nation-state, but this very challenge has led to the cmergence of nationalist reactions and to the legitimizing of subnational-seccesionist forces. As Hassner put it, 'the nation-state is both obsolete and obstinate'. 5 In Western Europe, the challenge to the nation-state comes primarily from the process of integration and globalization; in the historically imperial Eastern Europe, the challenge comes from a reconstructed national-romanic cthnic primordialism which can lead to the disconnection of the assumed unity of state and nation. As the locus of international security shifts in practice from the state to nation, the unchallenged and uncritical acceptance of the unity of the state and nation has become problematic. The amalgam of state/sovereignty is contested within and across international boundaries, as it is confronted by a competing amalgam: nation/identity. The implication is that although the state remains a central actor in the international system, it is not the sole actor in the area of security. Ethnonationalism and identity politics have system-transforming effects in international relations. ${ }^{6}$

In order to respond appropriately to the new conceptual - and eventually - policy challenges, we must do more than add new issues to the global agenda. Our thinking about the nature and pursuit of security must change. The attempt to understand the new European order and security should take account of its geographical and functional scope, its degrec of institutionalization, its strength and fragility and its ideological and normative elements. While the collapse of the Soviet block and accelerating globalization have fundamentally altered the structure of geopolitics, 'our conceptual frameworks and menu of policy prescriptions are indelibly infused with a Cold War political logic' 7 The definition of sccurity issues, the way in which they were analysed, and the policies that resulted were the product of the dominant geopolitical and idcological environment. Consequently, security was understood primarily in military terms, and security studies fixated on the problem of achicving and maintaining a stable balance of

${ }^{5} \mathrm{P}$. Hassner, 'Obstinate and Obsolete: Non-Territorial Transnational Forces versus the European Territorial State', in O. Tunander, P. Baev and V. I. Einagel (eds.), Geopolitics in Post-Wall Europe: Security, Territory and Identity, London, Oslo, 1997, p. 58.

${ }^{6}$ K. D. Bush and E. F. Keyman, Identity-Based Conflict: Rethinking Security in a Post-Cold War World', Global Governance, Vol. 3 (3), 1997, p 314.

7 Ibid., p. 311 . 
nuclear and conventional forces between two ideological-political blocks. The militarized conception of security that grounded intemational relations during the Cold War is being challenged by multifaceled and holistic conceptions. ${ }^{8}$ A threat to national security in Europe no longer necessarily evokes images of invading armics. It could be casily argucd that there are clear limitations to the application of conventional interstate-level analysis to the examination of international sccurity in general, and European sccurity in particular. Strategic studies are vicwed now as focusing on more than the use of military forec; security no longer presumes a principal concentration on challenges to a government and country from outside its borders; conflict no longer necessarily means only the violence of armed force; central governments are no longer viewed as the sole legitimate authoritics for the use of coercive means; defence no longer presumes that military force is cither the first or the most appropriate instrument.

All this amply proves that Laidi is right in stressing that the 'reconstruction of meaning or purpose' and its linking up with the exercise of (military) power cannot be settled through any idcological or telcological deintoxication which the proponents of Popper's open society seem to be advocating at times' 9 For all that, the divergence between meaning and power cannot be reduced to the tension between the integrating logic of the cconomy and the disintegrating dynamic of identity. It triggers off a 'chain' reaction affecting all the factors related to the exercise of political sovereignty, the most important of which being the military instrument. Russia provides the best cxample: while it remains by far the leading military power in Europe, the way we view the collapse of Russian power is governed less by its inherent weaknesses than by the fact that today there is no underlying plan to this power. Which leads us to the commonplace but nontheless essential observation: a military power, no matter how large, suffers a considerable loss of mcaning the moment it is unable to connect power with a military policy. ${ }^{10}$ The divergenec between military power and

${ }^{8}$ Sec, for example, K. Booth, 'Sccurity and Emancipation', Review of International Studies, Vol. 17, 1991, pp. 313-326; H. Haftendom, The Security Puzzle: Theory-Building and Discipline-Building in International Sccurity, International Studies Quarterly, Vol. 35, 1991, pp. 3-17; E. Kolodziej. 'Renaissance in Security Studies? Caveat Lector!', International Studies Quarterly, Vol. 36, 1992, pp. 421-438; B. Buzan, People, States and Fear: An Agenda for International Security Studies in the Post-Cold War Era, New York, 1991, Second Edition; M. Klare and D. Thomas (eds.), World Security: Challenges for a New Century, New York, 1994.

${ }^{9} Z$. Laidi, 'Introduction: Imagining the Post-Cold War Era', in Z. Laidi (ed.), Power and Purpose After the Cold War, Oxford, 1994, p. 2.

${ }^{10}$ Ibid., p. 3. 
military policy affects not just Russia but, to a lesser extent, the US and the other European powers.

Morcover, the replacement of the major military threat from the East by multi-level and multi-directional threats, though admittedly of lower tension, has lend great fluidity and instability to the European security system, which was not well-equipped in terms of policics, competencies and institutions to deal with it. It may well be true that the end of the Cold War provides an opportunity to raise the strategic threshold, and thercby reduce substantially the possibility of a global conflict; and while, this may be true for Europe, onc should not be too sanguine about the prospects for a 'pcace dividend' in many parts of the world, some of them scaringly close or even inside the 'Europcan perimeter'.

For all that, the new Europe makes prediction about the course of intcrnational politics difficult. The immense and unique problems posed in the post-Cold War world by the challenge of achicving security are pervaded with ambiguity and the dynamics of transformation. In 1990s, policy-makers confront circumstances that are morc diffuse, multiple and uncertain than those faced by carlier generations. The ending of the Cold War has loosened the bonds of patron-client politics, thereby giving licence to the rise of micronationalisms, encouragement to narrow sectoral interests, and legitimacy to unilateral efforts to redraw subnational, national, and even international boundaries. The rules are yet to be defined, where the true nature of threats remain shrouded by their multiplicity and complexity and where it is hard to judge what constitutes winning and losing. ${ }^{11}$ In straightforward terms, the end of the Cold War has removed the ultima ratio for crude distinctions between friends and focs, between primary and secondary conflicts. The result has becn a structural modification of the international stakes, from a vertical pattern (conflicts are not all of equal importance) to a more horizontal logic (conflicts are too complex and too specific for their settlement to be fungible). 12

Security challenges become even more complex when one turns to those issues that may not directly challenge the viability of the state, in traditional terms, but that may nevertheless undermine the sovereignty of the state, compromise its ability to control the penetrability of its borders, and exacerbate relations whether between groups within the polity or between states within the regional or global system. Increasingly, it is argued that individual and collective security are dependent on our ability to confront the

11 J. N. Rosenau, New Dimensions of Security: The Interaction of Globalising and Localising Dynamics', Security Dialogue, Vol. 25 (3), 1994, p. 255.

12 See Z. Laidi, 'Power and Purpose in the International System', in Laidi, Power and Purpose After the Cold War, p. 11. 
new challenges. Among the new factors that transcend boundaries and threaten to erode national cohesion, the most perilous are the so-called 'new risks': drug trafficking, transnational organised crime and nuclcar smuggling, refugec movements, uncontrolled and illegal immigration, and environmental risks. ${ }^{13}$ These are not new sources of potential conflict. They all existed to one extent or another during the Cold War, but were largely subsumed by the threat of military conflict between NATO and the Warsaw Pact. Responding to these threats, especially wide environmental degradation in the former Communist states, will be an important dimension of preventive defence. The political and economic costs of environmental degradation and mismanagement, such as the high discase rates and safety shortcomings in nuclear plants in the former Sovict Union, are proving to be formidable challenges to economic development and stability. The simple recognition of such problems, however, has not always elicited effective responses from the international community. Instead, nations have frequently opted to focus their energies on the more manageable manifestations of pending conflicts, such as arms buildups, that result from disagreements between nations over nontraditional security issues. 14

Because Europeans face so many difficult security challenges and promising opportunities, all of which competc for attention and resources, it will be difficult to tackle these kinds of non-traditional threats. However, some of them simply will not be ignored for long. The environmental threats posed by the aging nuclear infrastructure in Central and Eastern Europe and former Soviet states, inadequate controls over highly enriched uranium and other nuclear matcrials (including weapons-grade matcrials) in Russia, and the deterioration of nuclear powered vessels (some of which literally are rotting in port) could soon reach crisis proportion. These 'problems' have not gone unreported. However, much more needs to be accomplished if future disasters are to be avoided.

${ }^{13}$ Western European Union, European Security: a Common Concept of the 27 WEU Countries, WEU Council of Ministers, Madrid, 14 November 1995, pp. 8-14.

${ }^{14}$ The most prominent recent reminder of the need to take such threats seriously has been the Chemobyl nuclear reactor disaster in Ukraine. The Ukrainian government today still allocates nearly 15 per cent of its national budget to managing the environmental after effects. The total economic and social costs incurred across Europe, including increased health care expenditures and declining life expectancies, will probably never be accurately determined. Sec R. A. Hallenbeck, T. Molino and K. Roller, Preventive Defence: A New Framework for US-European Security Cooperation?, The Center for Global Security and Cooperation, Wilton Park, July 1997, p. 40. 
Refugee movements and uncontrolled and illegal immigration represents still another non-traditional threat to European security and stability. While the most publicised refugge flows in the past few years have occurred in Central Africa, more than 800,000 Bosnian refuges remain in Germany and other European states, and almost 500,000 Albanians entered Greece and Italy. Many other refugecs have resettled in Europe after flecing or immigrating from former colonics. The economic and social burdens these refugees place on government scrvices have become substantial. As a result, numerous countrics in Europe are beginning to recxamine their immigration policics and enforce more stringent standards. This could have a destabilizing effect on the less cconomically advanced nations in Europe and could threaten inter-statc relations. It also could lead to domestic unrest if more is not done soon to regulate the flow of refugges and expedite safe repatriation of those not accepted for long term residence. In the interim, Europe is experiencing an increase in crime rates and hate crimes, any of which could lead to instability and thence to conflict and insecurity. 15

These factors, probably as much as weapons of mass destruction proliferation (nuclcar, chemical and biological) and their means of delivery, and human-rights abuses, pose profound challenges to efforts to build a new global order as they are more than capable of contributing to violence and other forms of cocrcion. Contrary to other global challenges (the communications revolution, water shortages, access to energy resources, financial flows) they call directly into question the very authority of the state, and are therefore potentially, if not openly, subversive. This multifaceted conception of security entails a multifaceted approach to security. While an exclusively statc-centcred analysis is capable of illuminating some faccts of discord and conflict in the 1990s (for example, proxy wars and irredentism), it is limited by its one dimensional optic: distribution and character of military power. ${ }^{16}$ This multifaceted/multidimensional security concept means that there is no rigid link between a comprehensive concept for understanding a new situation and the quality of the responsc. On the contrary, a broad concept allows a flexible, tailored policy in which force is only one of the

15 Western European Union, European Security, p. 13.

${ }^{16}$ The best example is J. J. Mearsheimer, 'Back to the Future: Instability in Europe after the Cold War', International Securlty, Vol. 15(1), 1990, pp. 5-56. He argues that the demise of the Cold $W$ ar order is likely to increase the chances that war and major crises will occur in Europe: The next decades in a Europe without superpowers would probably not be as violent as the first 45 years of this century, but would probably be substantially more prone to violence than the past 45 years. This pessimistic conclusion rests on the argument that the distribution and character of military power are the root causes of war and peace' (p. 6). 
various means employed. ${ }^{17}$ In the final analysis, security is a politically defined concept. It is open to debate whether the widening of sccurity might be a good or a bad political choicc, but security is not intrinsically a sclfcontained concept, nor can it be related to military affairs only. If political prioritics change, the nature and the means of sccurity will incvitably follow and adapt to the different areas of political action. ${ }^{18}$

Finaly, security is multidimensional because individual welfare is more central to policy-making than it was fifty years ago. Individual security can no longer be satisficd only through military mcasures; it needs a multidimensional understanding. As Politi has noted, 'individual security and international stability are becoming increasingly interwined and a security threat is anything that hampers any relevant organization in ensuring individual sccurity' 19 That means that security is clusive; more than ever, it is embedded in the interaction of localising and globalising forces. The axes of conflict in the shadow of the Cold War will probably be more complex, not less, and more difficult to manage, not easicr. Policies begin to blur traditional dividing lines, both between jurisdictions and between concepts that were formerly discrete.

So, what does the discussion above mean for the prospects of cooperation in Europe? Contrary to the predictions of Mcarsheimer, and the complexity and unpredictability of post-Cold War world politics, today's anarchy and multipolarity do not necessarily undermine the prospects of cooperation, especially in Europe and in the Allantic arena. World politics should not be viewed as a historically frozen realm of power-hungry states, but rather as a dynamic process of interaction among individuals, groups, states, and international institutions, all of which are capable of adapting their sense of self-interest in response to new information and changing circumstances. Under the proper conditions and adaptive foreign policy responses to them, multipolar systems, not bipolar ones, can produce relatively greater stability.

This observation does not ignore the fact that the multipolar systems of the eightecnth and nineteenth centuries were structurally unstable. Moreover, the multipolar system of the cightecnth and nineteenth centuries did not avoid conflict and war. It used war to preserve the essential variables of the system, primarily the rights of the major powers, in a status of greater

${ }^{17}$ According to Politi, only in short-term lobbying battles is an alternative between prevention and repression seen'. See A. Politi, European Security: The New Transnational Risks, Chaillot Papers 29, WEU Institute for Security Studies, October 1997, p. 13.

${ }^{18}$ Ibid. p. 14. See also B. Buzan, 'Rethinking Security After the Cold War', Cooperation and Conflict, Vol. 32 (1), pp. 5-28.

19 Politi, European Security, p. 16. 
or lesser dynamic equilibrium. This was a dynamic equilibrium subject to much crosion at the edges and uncertainty as to the growth and decline of relative power positions. Europe's security problematique has changed too much in the 1990s and possible responses are too different to expect that future security dilemmas will be clones of those which plagued Europe in the past. In the cighteenth, nineteenth and much of the twenticth century the essential action in the global balance of power was in Europe. Since the end of the Cold War, the European continent is no longer necessarily the focus of shifting alignments and multilateral security. A balance of power could still be maintained in Europe but disorderly developments in Asia, the Middle East and elscwhere can affect negatively the stability of the European subsystem. In other words, although a stable Europe may be a necessary condition for world peace, it is by no means a sufficient condition. 20 Therefore, the connection betwcen multipolarity and European instability is rather simplistic. It could be argued that only when bipolarity is combined with other systemic conditions that European instabilitites may be exacerbated. In that sense, it is not polarity but polarization that can lead to conflictual situations. And there is no evidence that such a process will occur in the Europcan sub-systcm.

Detailed analyses elsewhere ${ }^{21}$ show that European and American national responses to the end of the Cold War were conditioned by the highly institutionalised European environment. Not only that, but European governments promoted 'institutionalisation' albeit in different forms (adaptation, reform, consolidation, ect.). This, however, does not mean that institutions have dictated policies. Rather, that they have been used to accommodate national interests and to promote national power and policy preferences in well known cooperative frameworks. It should not escape our attention that national positions and policies reflect decper antitheses which relate to fragile balances, national visions and external orientations and interests both within and outside the EU system of cooperation. These antitheses derive from the lack of homogeneity of geopolitical perspectives, differing concepts or evaluations of external threat and differing national strategies. The result has been a divergence among fundamental interests and consequently the development of divergent national strategic orientations, forcign policy preferences and approaches.

$20 \mathrm{~F}$. Carr and K. Ifantis, NATO in the New European Order, London, 1996, pp. 44-45.

${ }^{21}$ See, for example R. O. Keohane, J. S. Nye and S. Hoffmann (eds), After the Cold War: International Institutions and State Strategies in Europe, 1989-1991, Cambridge, Mass., 1993. Also, K. Ifantis, M. Tsinisizelis, et.al., Theory and Reform in the European Lnion, Manchester, 1999, especially chapters 4 and 5. 
Entering into the security realm is not uncontroversial considering that the EU for a long time professed to be a 'civilian power' lacking military might and ambitions in the military sphere. The European political system on the 'high politics' level is still fragmented into nation-state units which throughout history either used intergovernmental cooperation with participation in the Atlantic Alliance or developed bilateral cooperations, for example, France and Germany. This means that the Europcan countries have almost always had the will to integrate trade and economic policies, but not to abandon their authority and autonomy in the vital arcas of sccurity and defence which allow them to behave as independently as possible in the international system. The Europcan defence system was built - both on a collective and a national level - on the basis of an 'Atlantic' rather than a 'European' logic. The presence of the US in Europe 'undermined' the need for excessive defence armaments thus climinating the systemic causes of past Europcan conflicts. The historical significance of the American presence lies in the fact that it contained the traditional competitive and conflictual tendencies in Europe as well as developed a network of Euro-American institutions and processes in the framework of which defence and security policies were internationalised. What should be clcar is that American involvement and the Soviet threat Icd to 'Atlanticism' rather than the 'Europeanisation' of defence. The reactions of the major European powers to the tidal changes of the 1990s is a testament to this thesis. 'Institutionalization' was chosen as the principled European security policy: the Conventional Armed Forces (CFE) Treaty, the Confidence-and SecurityBuilding Measures (CSBM) agrecments, the Paris Charter, the creation of the North Atantic Cooperation Council (NACC) and the strengthening of CSCE/OSCE's conflict prevention and peacekecping machinery, NATO's 'Partnership for Pcace' as well as the decisions taken in Berlin (ESDI and CJTF) and in Madrid (NATO's enlargement) have already put the foundations of a new co-operative security order in place.

\section{Institutional Imperatives of System Change: NATO's New Rationale}

The discussion in the following pages considers briefly, and by no means extensively, the internal dimension of the institutional responses of the Atlantic Alliance to the gcopolitical and gcostrategic challenges of system change. It examines its development and analyses its relationship with the overall European institutional environment: what we have learned to call European 'sccurity architecture'. The relationship with the 'former enemies' and the enlargement strategy of the Alliance will not be dealt with, not because it does not represent an important element of the overall strategy, but because it clcarly touches upon the external dimension of it, thus going beyond the scope of the analysis here. 
Both NATO's origins and Cold War history are well known. What catalyzed NATO was a strong desirc to link Europe and the US (and Canada) in response to the Sovict threat. NATO mollificd European concerns about a German threat; contributed to a greater sense of West Europcan unity and security; and provided a mechanism for the US to participate in European cconomic and military reconstruction.

The pace of change in the European order was, however, spectacular and it fundamentally challenged NATO's rationalc and raison d'ctre. In just two short ycars (1989-1991), the core factors that had contributcd to NATO's creation (a divided Germany and the Sovict threat) were gone. For NATO member states, there was great relicf but great confusion as well. It was at this moment that many analysts predicted 'that absent the Sovict threat, NATO would cease to be an effective alliance', 22 or even worst, that 'is a disappcaring thing'. ${ }^{23} \mathrm{~A}$ decade later such predictions show little sign of coming true.

The Alliance responded by attempting to adapt to the new security environment, stressing its political rolc and reorienting its approach to issucs of military doctrine, sufficiency, and readiness. The process of change in the Alliance began in 1990. It was a process that would eventually result in significant reductions in funding and force lcvels for NATO's conventional and nuclear forces. Joint weapons programmes, annual military exercises, readincss, nuclear alcrt status, and training all have been sharply reduced.

More importantly, however, has been the fact that change meant that NATO was secking to anchor its position in the New Europe and establish the complementary nature of other security institutions. In Manfred Worner's words,'our future European architecture will rest on a system of different organisations, somctimes overlapping, but inter-locking and, albcit with a different focus, complementary'.24

\section{NATO's New Strategic Concept}

Against this background, NATO's ncw Stratcgic Concept, announced at Rome in November 1991, marked another turning point. The Strategic Concept reaffirmed the four core functions of the Alliance declared in June and went further in a new broad approach to security. Security was seen to

22 Mearsheimer, Back to the Future, p. 52.

${ }^{23}$ Kenneth Waltz argued so in testimony before the US Senate Foreign Relations Committee in November 1990. Quoted in R. B. McCalla, 'NATO's Persistence After the Cold War', International Organization, Vol. 50 (3), 1996, p. 471.

${ }^{24} \mathrm{M}$. Worner, 'The Atlantic Alliance in the New Era', NATO Review, Vol. 39(1), 1991. 
have political, cconomic, social, environmental and defence dimensions. Allicd sccurity was to adopt threc mutually reinforcing clements: dialogue, cooperation and collective defence. The objective of the strategy was to 'reduce the risks of conflict arising out of misunderstanding or design; to build increased mutual understanding and confidence among all European states; to help manage crises affecting the security of the Allies; and to expand the opportunities for a genuine partncrship among all European countrics in dcaling with common sccurity problems: ${ }^{25}$

In that context, the Concept was stressing the new political approach and understanding of security in Europe. In the new strategic circumstances the Alliance planncel to resolve crises at an carly stagc. It was recognised that this required a coherent strategy, which would coordinate a variety of conflict management measurcs. In June 1992 the Alliance announced it was willing to support, on a casc-by-casc basis, pcacckecping under the auspices of the CSCE. In December 1992 NATO pledged to support peacekceping under UN Sccurity Council authorisation.

The Stratcgic Concept finally underlined the importance of collective defence. The Concept states that the Alliance will maintain an adequate military capability and a clear preparedness to act collectivcly in the common defence. A commitment was made to retain a mixture of nuclear and conventional forces, though at a much reduced lcvel than in the past. NATO forces are however to be adapted to their new strategic roles. The overall size and readiness of forces was to be reduced. The maintenance of a lincar defence in the Central European region was to be ended. The Strategic Concept stressed flexibility, mobility and an assured capability for augmentation. NATO forces are to be capable of responding to a wide varicty of challenges and are to consist of rapid reaction and main defence components. The key element was that NATO forces should be able to 'respond llexibly to a wide range of possible contingencies'. The new strategic environment was seen to facilitatc a significant reduction in sub-stratcgic nuclear forces. Sub-strategic nuclear forces werc secn however as an important link with stratcgic nuclear forces, in particular those of the United States, which serve as the 'supreme guarantec' of Allied security.

The adoption of the Strategic Concept marked NATO's transition to the new security environment of Europe. The challenge for the Alliance was to reaffirm its security role in the new Europe and implement the new broad approach to strategy. In the immediate post-Cold War era, NATO retained its position as the primary forum for security in the new architecture. The revived WEU complemented NATO's institutional development in this period. As the relevant section below shows, WEU served to bridge NATO-

${ }^{25}$ NATO, 'The Alliance's New Strategic Concept', N^TO Review, Vol. 39(6), 1991. 
EU relations and to resolve for the forescable future the tension between a European defence and sccurity identity based upon the EU/WEU and the transatlantic basis that NATO provides.

A second feature of the new security architecture is the overlap of security in terms of its broader political interpretation. The broad approach to security adopted by NATO in its New Strategic Concept is reflected in the response of other institutions to the new Europcan order. Preventive diplomacy, crisis management, and pcacekecping are themes shared by NATO, the WEU, the EU, and the OSCE. The OSCE has some recognition as the over-arching organisation but is a considerable distance from being Europe's sccurity institution. Aspects of the OSCE role can also be seen in the EU's promotion of a Europcan Stability Pact and the work of the NACC. While the lack of institutional definition within the new security architecture is understandable, coordination remains imperative. The challenge of implementing the broader political aspects of strategy in the new Europe has been recognised by NATO in the necd for a coherent and cohesive management of responses to crises. This is a challenge not just for the Alliance but for the role and relationship of the 'interlocking institutions'. Thus, the Alliance had to transform its force structure in order to obtain and develop the capabilitics that would cnable it to deal with the new arising threats and challenges. The process was launched in September 1994, and the new military command structure was agreed upon on 2 December 1997.

The restructuring entails a reduction from the Cold War 65 headquarters to 20 in the new command structure. It consists of two overarching Strategic Commands (SC), one for the Atlantic and one for Europe, with threc Regional Commands under SC Atlantic and two under SC Europe. Reporting to the Regional Commands in Europe will bee Component Commands and Joint Sub-Regional Commands. It is envisaged that the new structure will enable the Alliance to perform the whole range of its roles and missions more effectivcly and flexibly, while providing suilable roles for participating allies integrating, at the same time the new members. 26

\section{Berlin 1996 or the End of the European Security Debate?}

The year was certainly annus mirabilis for it was then that the European Security and Defence Identily was clarified and the European security architccture secmed coming together. NATO in 1996 cxemplified a transition from the structures that emerged from the Cold War and from contained confrontation between the two superpowers to a new configuration

${ }^{26}$ In this context, it was determined that the accession of the C7ech Republic, Hungary and Poland would not require any additional NATO HQs. See NATO Review, Spring 1998, pp. 10-14. 
better adapted to the new geostrategic situation in Europe and the world at large. The crisis in former Yugoslavia gave it an opportunity to demonstrate that it can excrcisc its military prowess on condition that it has the firm political resolve of governments bchind it and that their objectives are clearly stated. The success of missions assigned to IFOR and work undertaken within the framework of PIP were evidence of the Alliance's ability to deal with present-day challenges and thus contribute to the political stability of the continent. 27

At the June 1996 ministerial mecting of North Allantic Council in Berlin, the idea was finally accepted of establishing European Security and Defence Identity within NATO and NATO's most radical plan, the CJTF concept, first introduced at the Brusscls NATO summit in January 1994, was refined and its development was authorized. 28 The Berlin outcome was the major turning point in the post-Cold War European security for it seuled (at least for the foresecable future) the fundamental issues affecting the transatlantic bargaining: the primacy of NATO; US leadership of (not only) NATO; the contribution of the Europeans to the alliance; and as a result the short and medium term - prospects of a self-containcd European security and defence identity.

The communique endorsed the continuing 'internal adaptation' of NATO and defined the CJTF concept as 'central to our approach for assembling forces for (NATO) contigency operations' and 'operations led by the WEU'. And the whole adaptation process would be 'consistent with the goal of building (ESDI) within NATO', cnabling 'all European Alics to play a larger role in NATO's military and command structures and, as appropriate, in contigency operations undertaken by the Alliance'. It also referred to 'a continued involvement of the North Amcrican Allies across the command and force structure', with the clcar aim of prescrving and reinforcing the transatlantic link.

However, the fundamental objective was the development of ESDI within NATO. CJTF would be a vital tool, leading to the 'creation of militarily coherent and effective forces capable of operating under the political control and strategic direction of the WEU'. The primary intent of the CJTF

27 Assembly of WEU, The Future Role of WEU.

${ }^{28}$ North Atlantic Council, 'Berlin Communique', Berlin, 3 June 1996, NA TO Review, Vol. 44(4), 1996. A lengthy document, the Berlin communique touched upon all the main issues facing NATO: the situation in former Yugoslavia and the conduct of IFOR; the spread of nuclear, biological and chemical weapons of mass destruction; outreach through NACC and PfP, and the enlargement timetable; relations with Russia and Ukraine; the role of the OSCE; the Middle East peace process; and disarmament and arms control. 
concept was to give NATO military forces the mobility and flexibility necded to execute the new tasks of the Alliance. Once fully in place, the new capabilitics would at last fulfill the 1991 Alliance Stategic Concept's call for military authoritics to design smaller, more mobile and more flexible forces. CJTF is a purcly military concept, a technique long bcing used by many forces in the conduct of contigency warfare. NATO has been institutionalizing the task force concept in order to make it more effective in the conduct of multilateral operations. 29

Paul Cornish, in an atempt to 'deconstruct' the CJTF concept, successfully identifies the constituent elements of its nature and political significance: 30 first, Berlin shows clcarly that NATO has firm ambitions to be a crisis manager and peacekecper in its own right, with the appropriate UN or OSCE mandate. CJTF is a means to achicve this goal. To that end, the idea of a division of labour belween NATO and the WEU, with the former responsible for collective defence (Article 5 operations) and the latler for lower-scale (non-Article 5) missions. If there is to be such a division of labour it could only be within the non-Article 5 category, with NATO taking 'hard' missions with fighting potential and the WEU dealing with 'soft' humanitarian and rescue tasks. In other words, non-Article 5 operations were not the exclusive preserve of WEU. Second, CJTF is not simply 'a Eurofriendly afterthought in NATO's restructuring process, but lics at the heart of that process' 31 It aims at providing an appropriate responsc across the spectrum of possible military lasks, ranging from the admittcdly unlikely collective defence to non-Article 5 necds for action. Third, via the NATOWEU diplomatic relationship, CJTF is the practical means by which the ESDI within the Alliance will be given operational expression. In political terms, it means that CJTF, as a US approved and NATO-sponsored idea, cnables a US-controlled development and implementation of ESDI. In the words of Comish, it is most unlikcly that a scrious rival to NATO could now develop: 32

What happened in Berlin was that NATO acquired even more credibility in matters of security and defence than any conccivable rival. Strong US leadership expressed not only the Alliance's post-Cold War adaptation drive, but also in the forcelull US commitment to the Dayton process and in the subsequent performance of IFOR, made NATO

${ }^{29}$ Sec C. L. Barry, 'NATO's CJTF Concept and the WEU's Role in Crisis Response', paper presented in WEU Athens Seminar, 1-3 May 1997.

$30 \mathrm{P}$. Cornish, 'European Security: the End of Architecture and the New NATO', International Affairs, Vol. 72(4), 1996, pp. 762-764.

31 According to $M$. Worner, the concept is the next logical step in the adaptation of our force structures'. Quoted ibid., p. 763.

32 Ibid., p. 764. 
increasingly attractive to almost cvery participant in the European security debate, including the French, ${ }^{33}$ and thus repositioned it firmly as the dominant determinant of the post-Cold War European security morphology. This was 'confirmed' in Amstcrdam where the progression from Common Forcign and Security Policy (CFSP) through Common Defence Policy to Common Defence secms to remain, at best, a long-term aspiration. The prospects for EU institution-building in defence proved indeed to be slim, 34 at least for the time being. Amsterdam recognised the WEU as 'an integral part of the development of the Union' and shall support (the Union) in framing the defence aspects of the common forcign security policy (...) with a view to the possibility of the integration of the WEU into the Union, should the European Council so decide' (Article J.7.1), but it is obvious that integrationist expectations have becn reduced to hollow political rhetoric. The main significance of the WEU is that it enabled a working compromise to be struck betwecn integration and intergovernmentalism, Allanticism and Europcanism. ${ }^{35}$ Without increased political, military, and financial commitment from the EU member states, it is hard to envisage the WEU becoming more than an - admittedly vital - political expedient and turning into a coherent, sclf-contained and military effective body, thus bringing defence into the European integration realm.

\section{Why NATO Endures}

The above discussion has been mainly about NATO's response and adaptation to the new world, the development of its strategies towards the

${ }^{33}$ France's so-called rapprochement with NATO is an important explanation for the Berlin outcome. In Fcbruary 1991, France announced its decision to take part in NATO's Strategy Review Group. Four years later, in December 1995, following NATO's decision to send 60,000 strong force to BosniaHerzegovina to replace UNPROFOR and the Anglo-French Rapid Reaction Force, France initiated its return to the alliance. French chicfs of staff would take part in NATO's Military Committec, would improve their relations with NATO's military staff and would work more closely with NATO's European command structure at SHAPE.

${ }^{34}$ The Article J.7, para. 1 of the Amsterdam treaty (former J.4 of the Maastricht Treaty) states that the common foreign and security policy shall include all questions relating to the security of the Union, including the progressive framing of a common defence policy (...) which might in time lead to a common defence, should the European Council so decide. (...) The policy of the Union in accordance with this Article shall not prejudice the specific character of the security and defence policy of certain Member States and shall respect the obligations of certain Member States, which see their common defence realized in NATO, under the North Atlantic treaty and be compatible with the common security and defence policy established within that framework'.

35 Comish, European Security, p. 768. 
new challenges as well as its success in formulating cffective policies. The issues were and still are especially salient given the new strategic landscape. What lics at the heart of the problem was the pressing necd to define NATO's rationale, not any more in terms of identifying a unifying threat, but in terms of combining the members' capabilities in a way that furthers their post-Cold War respective interests and consolidating itscle as a device to facilitate the making of substantive agrecments in world politics by providing rules, norms, principles, and procedures that help statc-actors to realise those interests collectively. 36

The challenge was cnormous as the possibility of detcrioration and dissolution was indecd real. Alliances detcriorate and dissolve for several reasons. The most obvious and important being a change in the identity or nature of threat that produced the original association. However, NATO endured. This durability has many sources. First, there is a leader, the US, strongly committed to prescrving the relationship and willing to expend the effort needed to kecp its allics from straying. American leadership is not on the wane but has becn exercised effectively through credible institutional structures. And that leads us to the second source of NATO persistence: it has become symbol of credibility and resolve. The albeit reluctant US decision to intervene in Bosnia (as well as its more recent resolute diplomatic response to the Kosovo crisis) appears to have been motivated and by the fear that failure to act would cast doubt on its reliability and therefore on NATO's futurc. Third, the high level of institutionalisation of NATO has created capabilitics that are certainly worth preserving despitc the extensive change in the array of extcrnal threats, especially since it obviously costs less to maintain them than it did to establish them in the first place. As Walt has indicated, 'the 1991 Gulf War could not have been fought without NATO assets, and the 1995 intervention in Bosnia relied on a similar base of infrastructure, military assets and joint decision-making procedures' ${ }^{37}$ The great level of institutionalisation within NATO worked most powerfully because it had creatcd capacitics that are highly adaplable. As the foregoing discussion shows, NATO durability was increased since its institutional profile was instrumental in amending doctrines and organisational forms in response to external developments, thereby making it casier to adapt to the new post-bipolar conditions. Fourth, idcological solidarity and a commitment to similar basic goals among NATO members, significantly helped to reduce intra-alliance conflicts and to sustain it long after its original rationale is gone. Not only that, but the fact that NATO has resulted in its members seeing themselves as integral parts of a larger (Atlantic) political community

${ }^{36}$ Carr/Ifantis, NATO in the New European Order, p. 158.

${ }^{37}$ S. M. Walt. 'Why Alliances Endure or Collapse', Survival, Vol. 39(1), 1997, p. 167. 
and reflected or even created a sense of common identity, mcans that the Alliance is undeniably appealing and therefore extremely robust.

Although, neither the history of the past 50 years nor the public statements of contemporary national lcaders offer an absolutcly rcliable guide for the future, the geostrategic developments and institutional dynamics of the 1990s resulted in NATO remaining the landmark of post-Cold War European sccurity. NATO still is preparing to deal with threats in true realist fashion, cven though their identitics are increasingly in disputc or uncertain. What NATO has done in response - to realist and ncorealist surprise - is to cxpand its relationship to other international institutions, such as the WEU and EU, 'as part of an effort to cmbed itself further into the framework of European, and to a lesser cxtent trans-Atlantic, rclations. In so doing, NATO has demonstrated the flexibility expected of both organizations and international institutions' 38

One can casily imagine, that these reasons which safeguarded NATO's efficient political and institutional adjustment, at the same time led to the decisions that were taken, or not taken, by the EU in Amsterdam. These decisions cast serious doubts as to whether the project of a true common European defence is still a real political objective being pursued by all governments of the relcvant European countrics', ${ }^{39}$ and once again fucls the debatc about the EU's role in world affairs and its nature as a global actor.

The critical variable here, is that the calls for a more autonomous European defence system which could be subject to supranational processes of integration should not ignore national strategies and preferences. Successful implementation of Common Forcign and Security Policy, Common Defence Policy and Common Defence will depend - as the Amsterdam outcome showed - less on legal obligations and more on favourable political and stratcgic variables and factors in the European regional and global arenas.

In that context, implementation of the decisions taken at Maastricht and Amstcrdam not only could be painful but it may actually dampen European forcign policy activism and threaten the whole aquis communitaire. Joint sccurity policics backed by military options are likcly to be possible under the Maastricht/Amsterdam Accords only when all the member-states' interests are under threat. Alternatively, they might refuse to comply with the

\footnotetext{
38 McCalla, NATO's persistence after the Cold War, p. 470.

${ }^{39}$ Assembly of the WEU, WEU After Amsterdam: the European Security and Defence Identity and the Application of Article $V$ of the Modiefied Brussels Treaty-Reply to the Annual Report of the Council, Draft Report, A/WEU/POL(97)10, Paris, 4 November 1997, p. 20.
} 
agreed guidelines. Amsterdam revealed that a modern European strategy document was not easy to write, given the very different foreign policy traditions of the different EU members and the uncertainty of the contemporary world. What Maastricht and Amsterdam have done is to identify defence as essential to EU construction. In such a context, a common security organisation becomes a means to a compelling political end. Given this imperative, practical issucs such as military planning, command structures, effectiveness and efficiency are in danger of becoming subordinate considerations. This is against all historical experience. The history of international relations since the Greck-Persian Wars has showed that states band together to meet perceived security threats; they do not forge defence structures to achicve a preconceived political federation. The implementation of Amsterdam stands this logic on its head. The accelcrated move to create a more than intergovernmental defence regime as an (implicit) precondition for eventual political union secms to ignore the fact that no functional equivalent to US strategic leadership exists in Europe, nor is one likcly to cmerge in the foresceable future. Morcover, regimes should not be viewed as progenitors of regional sccurity communitics that supplant national governments. This outcome is highly improbable and might in the end prove to be dangerous. If states perceive that regimes are being constructed around and under them, they are apt to withdraw their cooperation with adverse consequences for peace and stability in Europe. Instead, the regime-building process should draw from states their common interests in redefining the terms of an inter-state sccurity community in Europe, recognising non-state actors as critical supports for the process.

Also, successful regime-building requires identilication and definition of the threat. The NATO experience has showed that there is a linear relationship between the internal cohesion of an alliance and the way in which members perceive extcrnal threats and challenges. The nature of interstate relations in post-Cold War Europe has changed to such an extent that the definition of a specific and identifiable threat is very difficult. The Sovict threat has been replaced by a complex of fluid and 'sccondary' dangers: local or regional instability, civil and identity-based conflicts, revisionist tendencics in the regional sub-systems, nuclear proliferation and even potential resurrection of past dangers like nationalist groups and parties in Russia. Failure of the EU member-states to define the nature and character of post-Cold War threats could not only undermine the attempts to transform CFSP into 'defence policy', but could endanger the integration process in other ficlds. In that framework, the evolution of the European security institutional map in the 1990 s confirmed that the compelling task was not to create structures that derive from member-states' compulsions to assuage anxictics about the future, which will incvitably crode further the EU's credibility in defence and forcign policy by ignoring the heterogeneity of the European system, but to renovate the transatlantic security arrangements by 
shifting from a US-Ied system to a multilateral US-led and more EU-involved one.

It should be clcar, however, that this debate while focusing on failings and dilemmas and on persistent limitations, it does not ignore the progress that Europcan unity has madc. Bouts of expansion both in gcographical and functional scope have marked its history, and periods of pessimism and showdown have almosi never led to regressions. Stanlcy Hoffmann uses the image of Sisyphus only to suggest that the shape of the EU in the 1990s is quite different from the supranational dream of its founders and that cach leap forward brings with it problems as well as reminders of constant handicaps. ${ }^{40}$ However, prophecies of lethal breakups have not becn fulfilled. Instead, it sccms that Europcans, following Haas's suggestions, ${ }^{41}$ are trying to 'lcarn' and 'revaluc' themsclves by, at lcast, safeguarding their laboriously cvolving acquis. And this process of 'Icarning' and 'recvaluation' does lead to a - painfull and slow - institutional adaptation and policy innovation. The European Union is now a necessary, permanent and in some respect a leading part of the Europcan political and sccurity landscape, and thus a subtle, if often shaky, actor in international geopolitics. The reality is that we should not ignore the reality of the EU.

${ }^{40} \mathrm{~S}$. Hoffmann, The European Sisyphus: Essays on Europe, 19641994, Boulder, 1995, p. 6.

${ }^{41}$ See E. B. Haas, When Knowledge is Power: Three Models of Change in International Organizations, Berkley, 1990. 